\title{
Frequency of obesity and metabolic syndrome in childhood leukemia and lymphoma survivors
}

\author{
İbrahim Kartal ${ }^{1 *}\left(\mathbb{0}\right.$, , Abdurrahman Alaçam², Ayhan Dağdemir ${ }^{1}$, Cengiz Kara ${ }^{3}$, Oğuz Salih Dinçer ${ }^{1}$, \\ Canan Albayrak ${ }^{1}$ and Murat Elli ${ }^{4}$
}

\begin{abstract}
Objectives: In this study, it was aimed to determine the prevalence and clinical features of obesity and metabolic syndrome, which are long-term effects of survivors after treatment in children with leukemia and lymphoma.

Patients and Methods: Patients with leukemia and lymphoma, who were diagnosed between 2000 and 2012 (at least 2 two years after remission) were included. Data obtained through reviewing the family history, demographic characteristics, anthropometric measurements, and laboratory parameters (blood glucose, lipid, and insulin levels) were analyzed and compared at the time of diagnosis, after the treatment and at time of the study.

Results: Eighty nine patients (45 boys, 44 girls) were included (mean age: $14.7 \pm 4.3$ years): $77.5 \%$ had acute lymphoblastic leukemia, $11.2 \%$ had acute myeloid leukemia, and 11.2\% had lymphoma. Overall, $46 \%$ patients had received radiotherapy, $7 \%$ had undergone surgery, and $2.2 \%$ had received stem cell transplantation in addition to chemotherapy. The mean duration of treatment was 2.4 years, and the time elapsed after treatment was 4.9 years. While only one had obesity at the diagnosis, a significant increase in obesity (20\%), hypertension (15.7\%), hyperglycemia (15\%), insulin resistance (35\%) were observed at the time of study, and family history of hypertension, dyslipidemia, and cardiovascular diseases were significantly higher in this subgroup.

Conclusion: The prevalence of metabolic syndorme is higher in children with leukemia and lymphoma after treatment, and begins to increase with the initiation of treatment and continues to increase over time. These children should be followed-up for late-effects including metabolic syndrome through life-long period.
\end{abstract}

Keywords: Childhood leukemia-lymphoma, Obesity, Metabolic syndrome, Cancer survivor

\section{Introduction}

A large proportion of patients (approximately 60\%) who are long-term survivors of childhood cancer experience complications or "late effects" that reduce their survival chances or quality of life later in their lives as a result of long-term effects of cancer treatments [1]. Significant

\footnotetext{
*Correspondence: ibrahim_kartal28@hotmail.com

1 Division of Pediatric Hematology and Oncology, Department

of Pediatrics, Faculty of Medicine, Ondokuz Mayıs University, Samsun, Turkey

Full list of author information is available at the end of the article
}

advances have been made in the survival rates of patients with leukemia and lymphoma; particularly in the last few decades, 5 -year survival rates have reached $89 \%$ for acute lymphoblastic leukemia (ALL), 61\% for acute myeloid leukemia (AML), 96\% for Hodgkin lymphoma, and $89 \%$ for non-Hodgkin lymphoma [2]. This has led to the necessity of careful evaluation of long-term morbidity and mortality outcomes after treatments that provide a high survival advantage. The well-known long-term side effects of cancer treatments include hypertension (HT),

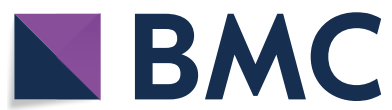

(c) The Author(s) 2022. Open Access This article is licensed under a Creative Commons Attribution 4.0 International License, which permits use, sharing, adaptation, distribution and reproduction in any medium or format, as long as you give appropriate credit to the original author(s) and the source, provide a link to the Creative Commons licence, and indicate if changes were made. The images or other third party material in this article are included in the article's Creative Commons licence, unless indicated otherwise in a credit line to the material. If material is not included in the article's Creative Commons licence and your intended use is not permitted by statutory regulation or exceeds the permitted use, you will need to obtain permission directly from the copyright holder. To view a copy of this licence, visit http://creativecommons.org/licenses/by/4.0/. The Creative Commons Public Domain Dedication waiver (http://creativeco mmons.org/publicdomain/zero/1.0/) applies to the data made available in this article, unless otherwise stated in a credit line to the data. 
dyslipidemia, impaired glucose metabolism, and obesity [3-6].

Obesity is an abnormal or excessive accumulation of body fat, defined by the World Health Organization as a body mass index (BMI) of $\geq 30 \mathrm{~kg}$ of body weight per square meter of height $\left(\mathrm{kg} / \mathrm{m}^{2}\right)$. The reported prevalence of obesity among adult survivors of childhood ALL ranges from 11 to $56 \%$ and varies based on reporting method and cohort characteristics [7].

The survivors of hematological malignancies are predisposed to the development of metabolic syndrome (MetS), which is a clinical picture formed by the combination of interrelated risk factors such as high blood pressure $[\geq 130 / 85 \mathrm{~mm}$ of mercury $(\mathrm{mmHg})]$, high waist circumference $(>102 \mathrm{~cm}(\mathrm{~cm})$ in males and $>88 \mathrm{~cm}$ in females), blood lipid disorders (triglyceride levels $>150 \mathrm{mg} / \mathrm{dl}$, high density lipoprotein cholesterol (HDL-C) $<40 \mathrm{mg} / \mathrm{dl}$ ), and impaired glucose tolerance (glucose $\geq 100 \mathrm{mg} / \mathrm{dl}$ ), which in turn increases the risk of cardiovascular disease (CVD) and type 2 diabetes $[8,9]$. Particularly, cardiovascular morbidity and mortality are noted to increase in cancer survivors [10].

In this study, we aimed to determine and present the prevalence of obesity and MetS in children with leukemia and lymphoma in post-treatment remission.

\section{Patients and methods}

\section{Study group}

Patients aged $\geq 6$ who were diagnosed with leukemia and lymphoma in Ondokuz Mayıs University, Faculty of Medicine, Department of Pediatrcis, Division of Pediatric Hematology and Oncology, located in the northern coast of Turkey, between 2000 and 2012 and survived at least 2 years after completing all their treatments were included in the study. The study was approved by the Ondokuz Mayıs University Clinical Research Ethics Committee.

\section{Methods}

In addition to the demographic data of the patients, family history, physical activities, sleep time, time spent in front of the screen, place of residence, family structure, and economic status were obtained. Anthropometric measurements and laboratory parameters (glucose, Total, HDL and LDL, cholesterol, Triglyceride levels, insulin level) were reviewed. Subgroups of the patients with and without obesity and MetS were compared with respect to these parameters.

\section{Data collection}

Demographic data were obtained from hospital records.

\section{Anthropometric measurements}

Bodyweight (BW) and height measurements of the patients were obtained and the body mass index (BMI) values were calculated at the diagnosis, at the end of treatment, and during the study at the last visit. These parameters were evaluated using the Turkish children percentile chart published by Neyzi et al. [11], and $\mathrm{z}$-score (SDS) values for BW, height, and BMI were calculated. The changes in BMI was revealed by calculating the differences among SDS values of BMI at the three steps of the study mentioned above. We used the parameters of the percentile values of waist circumference by Hatipoğlu et al., which reported for Turkish children aged between 7 and 17 years, to determine the percentile values of the waist circumference [12].

\section{Laboratory methods}

Serum glucose, insulin, triglyceride, and high-density lipoprotein (HDL) and LDL, cholesterol levels were tested on the same day using blood samples collected after 8-12 h of overnight fasting. Insulin resistance was evaluated using Homeostasis Model Assessment of Insulin Resistance [HOMA-IR; fasting insulin $(\mu \mathrm{U} /$ $\mathrm{ml}) \times$ fasting blood glucose $(\mathrm{mg} / \mathrm{dl}) / 405]$. A HOMA index of $\geq 2.5$ indicated insulin resistance.

\section{Definition of obesity and MetS}

Obesity was defined as a BMI of $\geq 95$ th percentile in children and adolescents and BMI of $\geq 30 \mathrm{~kg} / \mathrm{m}^{2}$ in those aged 18 years and above. Those with a BMI between the 85th and 95th percentile were considered overweight. Based on the measurements of waist circumference of Turkish children by age, those with a BMI of $>90$ th percentile were considered to have abdominal obesity.

MetS diagnostic criteria for children and adolescents published by the International Diabetes Federation (IDF) in 2005 were used to determine MetS [13]. According to IDF, patients were categorized into the three following groups based on age: 6 to $<10,10$ to $<16$, and $>16$ years. Central obesity was the main criteria for all age groups. Between the ages of 6 and 10, waist circumference above the 90th percentile and family history were enough for MetS with no need for biochemical features. For those aged $>10$ years, two of the four criteria were sought in addition to obesity. The presence of HT was comfirmed if the patient receiving antihypertensive medication or having measurements higher than the $130 / 85 \mathrm{mmHg}$ by IDF. HT in children aged $<10$ was defined as being above the 95th percentile according to the Turkish childhood percentile values determined by Tümer et al. [14]. 


\section{Statistical analysis}

The descriptive statistics were expressed as frequency distributions and percentages for categorical data and mean and standard deviation or median and minimummaximum values for numerical data. Chi-square statistics were used to compare categorical data and Mann-Whitney $U$ statistics were used to compare numerical data between independent data groups of the study. All analyses were evaluated based on two-tailed hypothesis test with a 5\% probability for making a type-I error. Statistical analyses were performed using SPSS software version 21 (IBM Corp., Armonk, NY, USA).

\section{Results}

Eigthy nine patients were eligibile for the study: 69 acute lymphoblatic leukemia, 10 acute meyloblastic leukemia, 10 lymphoma. Boys were $50.6 \%$ and girls were $49.4 \%$ of them, and the median and mean ages were $15.3(7-22.3)$ and $14.7 \pm 4.3$ years, respectively (Table 1 ). Patients aged $\geq 16$ years constituted the largest age group, including $44.9 \%$ patients. In terms of birth weight, $79.8 \%$ patients were appropriate for gestational age.

Regarding diagnostic characteristics of the patients, it was found that $77.5 \%$ had ALL, $11.2 \%$ had AML, and $11.2 \%$ had lymphoma; the mean age at diagnosis was $7.4 \pm 4.3$ years, and BMI at diagnosis was $17 \pm 2.4 \mathrm{~kg} /$ $\mathrm{m}^{2}$. Based on these BMI values, $88.8 \%$ patients were classified as having a normal weight.

When the treatment characteristics and end-of-treatment measurements were examined, it was seen that $46.1 \%$ patients received radiotherapy (RT), $6.7 \%$ underwent a surgical procedure, and $2.2 \%$ underwent stem cell transplantation. The mean duration of treatment was $2.4 \pm 0.8$ years, and BMI at the end of treatment

Table 1 Anthropometric measurements of the patients

\begin{tabular}{|c|c|c|c|c|}
\hline & Entire group $(n=89)$ & Male $(n=45)$ & Female $(n=44)$ & p-value \\
\hline \multicolumn{5}{|l|}{ Body weight } \\
\hline Kilograms, Mean \pm SD & $56 \pm 19.1$ & $61.5 \pm 19.9$ & $50.3 \pm 16.6$ & \\
\hline Percentile, Median (min-max) & $62(1-100)$ & $64(3-100)$ & $59(1-100)$ & 0.525 \\
\hline SD score, Median (min-max) & $0.4(-2.2-4)$ & $0.4(-1.8-3.3)$ & $0.4(-2.2-4)$ & 0.608 \\
\hline \multicolumn{5}{|l|}{ Height } \\
\hline Centimeters, Mean \pm SD & $155.4 \pm 16.9$ & $160 \pm 18$ & $150.7 \pm 14.5$ & \\
\hline Percentile, Median (min-max) & $50(1-97)$ & $46(2-97)$ & $52(1-84)$ & 0.977 \\
\hline SD score, Median (min-max) & $0(-2.6-2)$ & $-0.1(-2.1-2)$ & $0.1(-2.6-1.2)$ & 0.938 \\
\hline \multicolumn{5}{|l|}{ Body Mass Index } \\
\hline $\mathrm{kg} / \mathrm{m}^{2}$ Mean $\pm \mathrm{SD}$ & $22.4 \pm 4.6$ & $23.4 \pm 4.5$ & $21.5 \pm 4.5$ & \\
\hline Percentile, Median (min-max) & $67(3-100)$ & $66(4-100)$ & $69(3-100)$ & 0.329 \\
\hline SD score, Median (min-max) & $0.4(-1.9-3.4)$ & $0.4(-1.8-2.9)$ & $0.5(-1.9-3.4)$ & 0.337 \\
\hline \multicolumn{5}{|l|}{ BMI classification, n (\%) } \\
\hline Obese & $18(20.2)$ & $11(22.4)$ & $7(15.9)$ & 0.814 \\
\hline Overweight & $12(13.5)$ & $6(13.3)$ & $6(13.6)$ & \\
\hline Normal weight & $57(64)$ & $27(60)$ & $30(68.2)$ & \\
\hline Underweight & $2(2.2)$ & $1(2.2)$ & $1(2.3)$ & \\
\hline \multicolumn{5}{|l|}{ Waist circumference, Mean \pm SD } \\
\hline Centimeters, Mean \pm SD & $74.2 \pm 12.5$ & $78.7 \pm 12$ & $69.6 \pm 11.5$ & \\
\hline Percentile, median (min-max) & $74.9(60-94)$ & $81.1(60-94)$ & $73.7(60.1-81.1)$ & $<0.001$ \\
\hline \multicolumn{5}{|c|}{ Waist circumference classification, n (\%) } \\
\hline Normal & $57(64)$ & $26(57.8)$ & $31(70.5)$ & 0.213 \\
\hline Obese & $32(36)$ & $19(42.2)$ & $13(29.5)$ & \\
\hline \multicolumn{5}{|l|}{ Blood pressure, mean $\pm S D$} \\
\hline Systolic & $111.4 \pm 15.4$ & $115.4 \pm 15.4$ & $107.2 \pm 14.4$ & 0.013 \\
\hline Diastolic & $68.9 \pm 10$ & $70.7 \pm 10.6$ & $67.1 \pm 9$ & 0.150 \\
\hline \multicolumn{5}{|l|}{ Blood pressure classification, n (\%) } \\
\hline Normotensive & $75(84.3)$ & $34(75.6)$ & $41(93.2)$ & 0.022 \\
\hline Hypertensive & 14(15.7) & $11(24.4)$ & $3(6.8)$ & \\
\hline
\end{tabular}

$S D$ standard deviation, $B M I$ body mass index 
Table 2 Variation in anthropometric measurements over time

\begin{tabular}{|c|c|c|c|c|}
\hline & At diagnosis & At the end of the treatment & At the time of study & p-value \\
\hline \multicolumn{5}{|l|}{ Body weight } \\
\hline Kilograms, Mean \pm SD & $27.3 \pm 14.8$ & $39.4 \pm 16.1$ & $56 \pm 19.1$ & \\
\hline Percentile, Median (min-max) & $48(1-95)$ & $46(1-136)$ & $62(1-100)$ & $<0.001$ \\
\hline SD score, Median (min-max) & $-0.1(-2.4-1.6)$ & $-0.04(-2.4-2.5)$ & $0.4(-2.2-4)$ & $<0.001$ \\
\hline \multicolumn{5}{|l|}{ Height } \\
\hline Centimeters, Mean \pm SD & $121.6 \pm 24.6$ & $133 \pm 22.1$ & $155.4 \pm 16.9$ & \\
\hline Percentile, Median (min-max) & $42(2-99)$ & $33(1-99)$ & $50(1-97)$ & $<0.001$ \\
\hline SD score, Median (min-max) & $-0.2(-2-2.3)$ & $-0.44(-2.6-2.5)$ & $0(-2.6-2)$ & $<0.001$ \\
\hline \multicolumn{5}{|l|}{ Body mass index } \\
\hline $\mathrm{kg} / \mathrm{m}^{2}$, Mean $\pm \mathrm{SD}$ & $17 \pm 2.4$ & $18.6 \pm 3.1$ & $22.4 \pm 4.6$ & \\
\hline Percentile, Median (min-max) & $48(1-96)$ & $56(1-100)$ & $67(3-100)$ & $<0.001$ \\
\hline SD score, Median (min-max) & $0.1(-5.2-3.5)$ & $0.18(-2.5-2.9)$ & $0.4(-1.9-3.4)$ & 0.603 \\
\hline \multicolumn{5}{|l|}{ BMI classification, n (\%) } \\
\hline Obese & $1(1.1)$ & $12(13.5)$ & $18(20.2)$ & $<0.001$ \\
\hline Overweight & $6(6.7)$ & $10(11.2)$ & $12(13.5)$ & \\
\hline Normal weight & 79 (88.8) & $66(74.2)$ & $57(64)$ & \\
\hline Underweight & $3(3.4)$ & $1(1.1)$ & $2(2.2)$ & \\
\hline
\end{tabular}

$S D$ standard deviation, $B M I$ body mass index

was $18.6 \pm 3.1 \mathrm{~kg} / \mathrm{m} 2$. According to these BMI values, $13.5 \%$ patients were obese and $11.2 \%$ were overweight. Furthermore, the mean elapsed time after treatment was $4.9 \pm 2.9$ years.

The changes in anthropometric features measured at diagnosis, at the end of treatment, and during the study are summarized in Table 2. All anthropometric measurements showed a significant increase over time, and the obesity rates of the patients also increased over time (Fig. 1).

There was no significant difference between sexes in terms of BW SDS, height SDS, BMI SDS, and waist circumference percentile values; however, high systolic blood pressure were found to be significantly higher in boys $(\mathrm{p}=0.013)$. When the BMI categories (obese + overweight and normal + underweight) were compared in terms of sex, no significant difference was observed $(\mathrm{p}=0.411)$.

When the lifestyle and social characteristics of the patients were evaluated, it was found that $68.5 \%$ spent $>3 \mathrm{~h}$ in front of a screen, $55.1 \%$ had physical activity within normal limits, $56.2 \%$ slept between 6 and $9 \mathrm{~h}, 86.5 \%$ had a nuclear family structure, $52.8 \%$ had an income of 1300-4000 TL (350-1100\$), and 73\% lived in urban areas. When the lifestyle and social characteristics of the groups compared according to the presence of MetS, patients with MetS performed less physical activity $(\mathrm{p}=0.023)$.
On evaluating the family histories of patients, it was found that $31.5 \%$ of patients had a family history of HT, $14.6 \%$ had a family history of diabetes mellitus (DM), $60.7 \%$ had a family history of obesity, and $22.5 \%$ had a sibling with obesity; moreover, $20.2 \%$ and $25.8 \%$ patients had a family history of dyslipidemia and CVD, respectively.

When family histories were evaluated, it was observed that the presence of HT $(\mathrm{p}<0.001)$, dyslipidemia $(\mathrm{p}=0.003)$, and CVD $(\mathrm{p}<0.001)$ in the family was significantly high in patients with MetS.

The diagnostic features of patients with MetS are summarized in Table 3 . Weight percentile $(p=0.013)$ and weight percentile SD $(p=0.017)$ values at diagnosis and BMI percentile $(\mathrm{p}=0.011)$ and $\mathrm{SD}(\mathrm{p}=0.046)$ values at diagnosis were significantly high in patients with MetS (Fig. 2). The time elapsed after treatment (mean \pm SD) of the groups of those with MetS or not were $4.9 \pm 2.9$ and $4.9 \pm 3.0$ years, respectively, ( $p$ 0.894).

The retrospective evaluation of the groups at the diagnsosis revealed no significant difference of the obese + overweight and normal+ underweight groups categorized according to the BMI at diagnosis revealed that the rates of insulin resistance $(p=0.717)$, obesity $(\mathrm{p}=0.167)$, and MetS $(\mathrm{p}=0.107)$ (Table 4).

According to the results of biochemical evaluations, it was determined that $14.6 \%$ patients had hyperglycemia, $31.5 \%$ had low HDL, $11.2 \%$ had high triglyceride levels, 


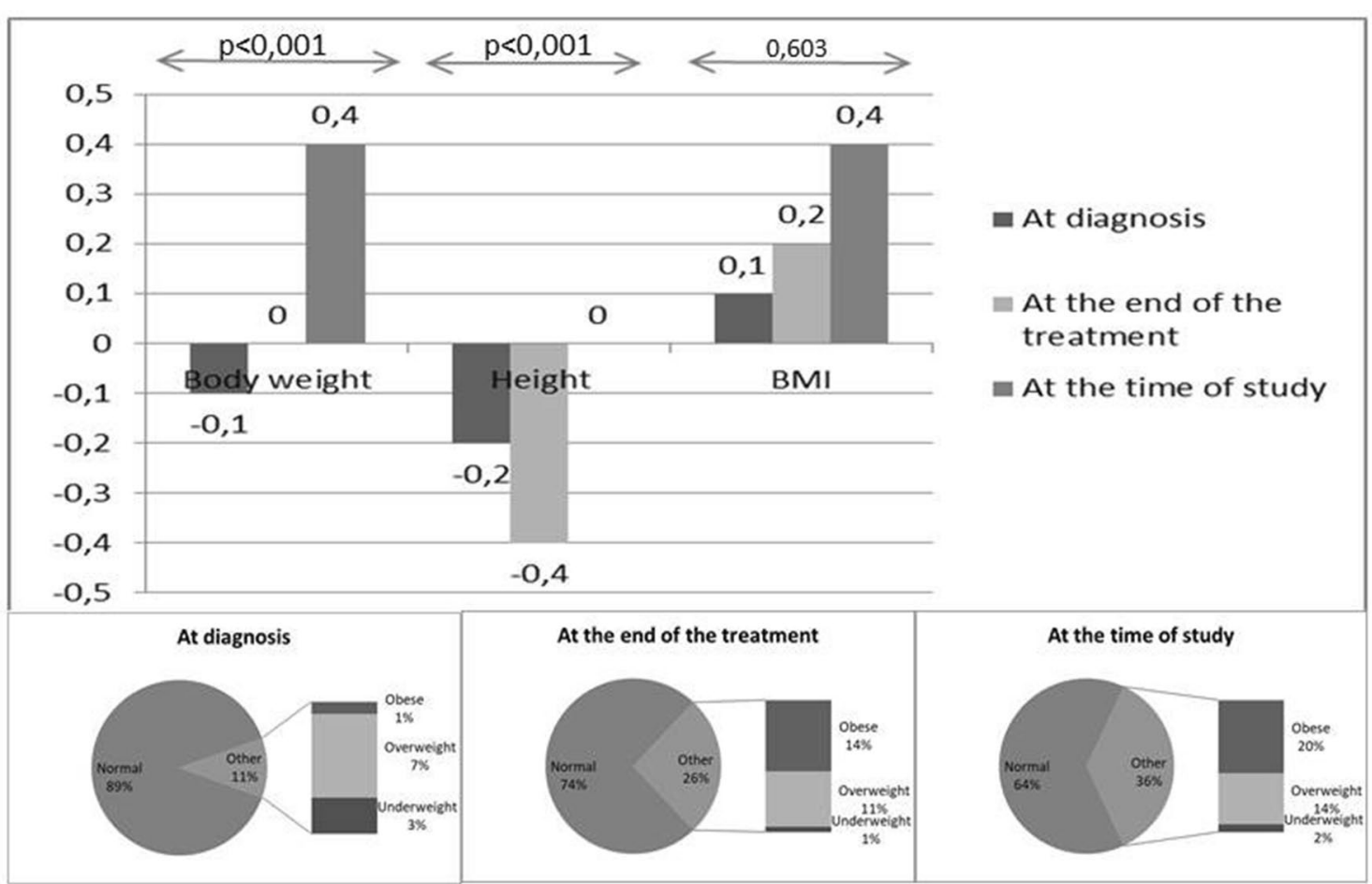

Fig. 1 Variation in anthropometric measurements over time

Table 3 Diagnostic features of patients with and those without metabolic syndrome

\begin{tabular}{|c|c|c|c|}
\hline & MS $(-)(n=73)$ & MS $(+)(n=16)$ & p-value \\
\hline \multicolumn{4}{|l|}{ Diagnosis, n (\%) } \\
\hline ALL & $55(75.3)$ & $13(87.5)$ & 0.379 \\
\hline AML & $10(13.7)$ & $0(0)$ & \\
\hline Lymphoma & $8(11)$ & $2(12.5)$ & \\
\hline Age at diagnosis, Mean \pm SD & $7.8 \pm 4.4$ & $5.7 \pm 3.4$ & 0.097 \\
\hline \multicolumn{4}{|l|}{ Weight at diagnosis } \\
\hline Kilograms, Mean \pm SD & $28.5 \pm 15.6$ & $22 \pm 8.6$ & \\
\hline Percentile, Median (min-max) & $44(1-92)$ & $64(1-95)$ & 0.013 \\
\hline SD score, Median (min-max) & $-0.2(-2.4-1.4)$ & $0.3(-2.2-1.6)$ & 0.017 \\
\hline \multicolumn{4}{|l|}{ Height at diagnosis, Mean \pm SD } \\
\hline Centimeters, Mean \pm SD & $123.4 \pm 25.6$ & $113.3 \pm 18.5$ & \\
\hline Percentile, Median (min-max) & $42(4-95)$ & $45(2-99)$ & 0.532 \\
\hline SD score, Median (min-max) & $-0.2(-1.8-1.6)$ & $0.1(-2-2.3)$ & 0.326 \\
\hline \multicolumn{4}{|l|}{ BMI at diagnosis, Mean \pm SD } \\
\hline BMI, Mean \pm SD & $17.1 \pm 2.6$ & $16.6 \pm 1.2$ & \\
\hline Percentile, Median (min-max) & $46(1-89)$ & $65.5(5-96)$ & 0.011 \\
\hline SD score, Median (min-max) & $0(-5.2-3.5)$ & $0.4(-1.7-1.8)$ & 0.046 \\
\hline \multicolumn{4}{|l|}{ BMI classification at diagnosis, n (\%) } \\
\hline Obese & $0(0)$ & $1(6.3)$ & 0.063 \\
\hline Overweight & $4(5.5)$ & $2(12.5)$ & \\
\hline Normal weight & 67 (91.8) & $12(75)$ & \\
\hline Underweight & $2(2.7)$ & $1(6.3)$ & \\
\hline
\end{tabular}




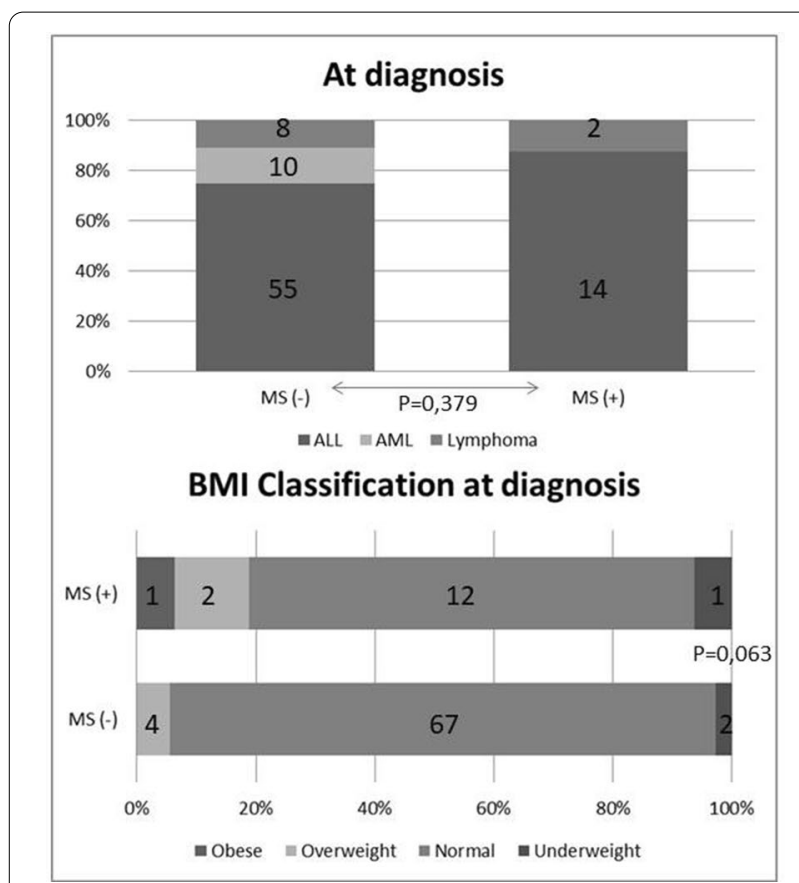

Fig. 2 Diagnostic features according to the presence of metabolic syndrome

Table 4 Insulin resistance, obesity and metabolic syndrome rates according to $\mathrm{BMI}$ at diagnosis

\begin{tabular}{llll}
\hline & \multicolumn{3}{l}{ BMI at the time of diagnosis } \\
\cline { 2 - 4 } & $\begin{array}{l}\text { Obese + Overweightn } \\
\mathbf{( \% )}\end{array}$ & $\begin{array}{l}\text { Normal + Low } \\
\text { Weight } \mathbf{n}(\%)\end{array}$ & p-value \\
\hline $\begin{array}{l}\text { Insulin resistance } \\
\text { Obesity }\end{array}$ & $2(28,6)$ & $29(35,4)$ & 0.717 \\
$\begin{array}{l}\text { Metabolic syn- } \\
\text { drome }\end{array}$ & $3(14,3)$ & $17(20,7)$ & 0.167 \\
\hline
\end{tabular}

and $34.8 \%$ had insulin resistance at the diagnosis and there was no high total cholesterol levels that could effect the cardivascular risk.

When patients were analyzed in terms of risk factors included in the definition of MetS (i.e., abdominal obesity, HT, low HDL, high triglycerides, and fasting hyperglycemia), at least one risk factor was present in 60 $(67.4 \%)$ patients, at least two in $24(26.9 \%)$, at least three in $12(13.4 \%)$, and four in one (1.1\%) patient.

\section{Discussion}

Childhood cancer continues to be an important health concern. Owing to the improvements in chemotherapy and supportive treatments, the survival rates in childhood cancers have increased and the long-term survival rates are gradually increasing [2]. Therefore, the longterm morbidity and mortality outcomes of treatments that provide a survival advantage need to be carefully evaluated. The frightening increase in childhood obesity in recent years has resulted in increased prevalence of MetS, a significant problem, particularly in adolescents. It was revealed that obesity, HT, hyperlipidemia, DM, and consequently, MetS and CVDs are seen more frequently in patients who have been treated for leukemia and lymphoma those in general population. Moreover, they carry the risk of being diagnosed with MetS and CVDs at an earlier age [7].

Although there are numerous other studies that describe weight gain during ALL therapy as well as the presence of obesity in ALL survivors, recent studies show that weight gain during induction as a potential predictor for later obesity, most likely due to glucocorticoids [15]. Long-term use of corticosteroids in lymphoreticular malignancies, unlike solid tumors, must be the major factor for obesity in children, but we were not able to compare whether corticosteroids or any other drugs to cause obesity and MetS in our children because all them received the same drugs in this study.

Because obesity is a multifactorial disease affected by genetic, behavioral, environmental, and cultural factors, its prevalence is expected to be different in studies from different regions. In 1975, the prevalence of overweightedness and obesity in most European countries was $<10 \%$ and $<5 \%$, respectively, whereas in 2016 , this trend had reversed, showing an alarming increase in the number of European countries with an increased prevalence of overweightedness $(>30 \%)$ and obesity $(>10 \%)$ [16]. In the USA, the National Health and Nutrition Examination Survey reported that $16.3 \%$ of children and adolescents are obese [17]. In Turkey, the rate of obesity in children varies between 6 and 10\% and the rate of overweight children varies between 8 and 15\% [18, 19]. In a study conducted by screening a total of 4120 secondary and high school students in Samsun, the region in which our hospital provides healthcare services, the prevalence of obesity was found to be $7.3 \%$ in girls and $4 \%$ in boys, with an overall prevalence rate of $5.5 \%$ [20].

In this study, obesity and overweightedness were detected in $1(1.1 \%)$ and $6(6.7 \%)$ cases at the time of diagnosis and in $12(13.5 \%)$ and $10(11.2 \%)$ cases at the end of treatment, respectively. On the last visit, the number of obese and overweight patients had increased to $18(20.2 \%)$ and $12(13.5 \%)$, respectively. This dramatic increase in obesity and overweightedness was also statistically significant $(\mathrm{p}<0.001)$.

When the patients were examined during the study, a total of 30 overweight cases (33.7\%) were detected; $18(20.2 \%)$ cases were obese; and $12(13.5 \%)$ cases were 
overweight. Compared to the data of Turkey, the rate of overweightedness in our patients was similar to that in the normal population, while the rate of obesity in our patients was significantly higher than that in the normal population. This result, which is consistent with the literature, shows an increased prevalence of obesity in patients who are treated for cancer in childhood compared with that in the healthy population.

In this study, there were $16(18 \%)$ cases that met the criteria of MetS. The prevalence of MetS was found to be higher than that of the general population and similar to the rates observed in different studies conducted with patients who received cancer treatment. When the patients were analyzed in terms of risk factors included in the definition of MetS (i.e., abdominal obesity, HT, low HDL, high triglycerides, and fasting hyperglyce$\mathrm{mia}$ ), at least one risk factor was present in 60 (67.4\%) patients, at least two in $24(26.9 \%)$, and at least three in $12(13.4 \%)$ patients. Although there are many studies and prevalence data on obesity and MetS in individuals treated for childhood cancers, the underlying pathophysiological processes and mechanisms contributing to the increased CVD risk are still unknown, and the etiology is thought to be multifactorial. Potential mechanisms for the increased risk of MetS include disruptions in leptin and adiponectin levels, early adiposity rebound, pancreatic insufficiency, poor dietary habits, sedentary lifestyle, and changes in the gut microbiome composition [21-23]. Frequent absenteeism from school during treatment increase inactivity. During treatment, parents tend to be overprotective, limit outdoor activities, and overfeed their children [24]. The reasons that decrease physical activity in children with cancer are general malaise, muscle weakness, osteopenia, decreased lung functions, and cardiomyopathy in addition to low self-confidence [25].

Corticosteroids and asparaginase used in the treatment of leukemia and lymphoma are thought to have effects on glucose metabolism [26]. Insulin resistance was detected in $31(34.8 \%)$ of the 89 patients in our study, whereas impaired fasting glucose was detected in $13(14.6 \%)$ patients. Nine (10.1\%) patients had both insulin resistance and impaired fasting glucose. Consistent with the literature, the prevalence of insulin resistance and impaired fasting glucose was found to be high in patients who had leukemia and lymphoma treatment [27]. Among the patients with insulin resistance, $45.2 \%$ were obese $(n=14), 9.7 \%$ were overweight $(n=3), 41.9 \%$ had normal weight $(\mathrm{n}=13)$, and $3.2 \%$ were underweight $(\mathrm{n}=1)$. Although insulin resistance was more common in the obese group, the difference was not statistically significant. Insulin resistance was observed in 17 $(39.5 \%)$ patients aged $<6$ years and $14(34.5 \%)$ patients aged $\geq 6$ years at the time of diagnosis. Although a higher rate of insulin resistance was observed in those aged $<6$ at the time of diagnosis, the difference between the two age groups was not statistically significant.

It is not fully known why blood pressure increases in post-treatment cancer survivors [28]. It has been suggested that endothelin dysfunction plays an important role in the development of CVDs [29]. Chemotherapy agents, such as alkylating agents, and RT damage vascular structures [30]. In studies conducted among the survivors of childhood ALL, the prevalence of HT (1346.4\%) was reported to be higher than that in the normal population [31-35]. However, in a few studies, none of the survivors had HT [36, 37]. In this study, HT was detected in 13 (14.6\%) patients, and a higher rate of HT was observed in boy patients. The high frequency of HT in patients with leukemia and lymphoma indicates that blood pressure measurement should be a part of the routine outpatient examination in these children.

In the literature, it has been stated that receiving leukemia and lymphoma treatment at an earlier age (especially at $<5$ years of age) is a risk factor for the development of late effects [38, 39]. It is known that early adiposity rebound in childhood is associated with an increased risk of obesity in adulthood. Adiposity rebound usually occurs between the ages of 5 and 7 years. Because ALL is frequently noted between the ages of 3 and 5 years, chemotherapy and RT may cause early adiposity rebound in these cases and may be the cause of obesity [40-43]. In the study by Razzouk et al., it was determined that age of $<6$ years at the time of diagnosis is a risk factor for being overweight/obese in adulthood [44]. In a study conducted on ALL survivors in İzmir, the rate of obesity was higher in those diagnosed at the age of $<6$ years than in those diagnosed at the age of $>6$ years, and this difference was statistically significant [45]. In this study, although obesity and MetS rates were higher in those aged $<6$ years and diagnosed with leukemia, this difference was not statistically significant. In addition, although the mean age at diagnosis of patients with MetS was lower than that of patients without MetS, this difference was not statistically significant.

Recently, some studies have stated that being overweight/obese at the time of diagnosis is the most important risk factor for the development of overweightedness/ obesity in patients with cancer rather than other defined risk factors. This suggests that possible genetic and familial factors that may lead to obesity in patients are more prominent $[44,46,47]$. In our study, only one had obesity at the time of diagnosis who also obese at the last visit, but it was found that $31.5 \%$ had a family history of HT, $14.6 \%$ of DM, $60.7 \%$ of obesity, $25.8 \%$ of CVD, and $20.2 \%$ of dyslipidemia and $22.5 \%$ had a sibling with obesity. In 
the subgroup of MetS, the presence of HT ( $<<0.001)$, dyslipidemia $(p=0.003)$, and CVD in the family was found to be significantly high $(\mathrm{p}<0.001)$ and identified as a positive risk factor for the development of this syndrome. The fact of the higher prevalence of MetS in this study than those in healthy population of our region may suggest that MetS is primarily affected by environmental (chemoradiotherapy) and nutritional habits rather than familial factors, such as genetics. However, studies with larger groups can be conducted to obtain more definitive results.

Studies emphasize that nutritional habits and socioeconomic level of the family contribute toward developing childhood obesity $[47,48]$. When the data in our study were examined, $16 \%$ patients were determined to have low income, $52.8 \%$ had moderate-income, and $29 \%$ had high income; additionally, $86.5 \%$ patients had a nuclear family structure and $73 \%$ lived in urban areas, and no significant difference was found between the group with MetS and that without MetS in terms of socioeconomic data.

Our patients have already been in childhood period and the increased risk factors for CVD could be expected over time.This fact requires regular follow-up of these patients in terms of the risk factors for CVD. Considering that most risk factors can be modified with lifestyle changes and medical interventions, cancer survivors should be encouraged to engage in preventive health care and healthy behaviors. Periodic follow-up of patients allows early detection and treatment of the risk factors that lead to the development of MetS and enables us to provide preventive suggestions such as proper nutrition and exercise, which aim to prevent a sedentary lifestyle that plays a role in the development of obesity. The probability of the follow-up of childhood cancer survivors in a cancer center or by an oncologist decreases in over time [49]. Therefore, it is important for family physicians, pediatricians, and internists to be aware of the risks in this population.

The lock of LDL-c measurements, family genetic and omic analysis due to technical problems and limited opportunities were among the limitations of the study. It was not planned as a randomized prospective study, and did not include large groups because of it was done in only one center.

\section{Conclusion}

We found an increased frequency of obesity and MetS in children who received chemotherapy and other debilitating treatments such as radiotherapy for leukemia and lymphoma when compared to the baseline values, and we conclude that they become more prone to obesity and MetS as compared to the literature in general population. Emergency preventive measures are required in these lucky children who survived of cancer, so we can prevent some risks of serious health problems in later of life. Further prospective studies including control groups as well as in larger patients and more long-term follow-up periods are needed.

\section{Abbreviations \\ SD: Standart deviation; BMI: Body mass index; MetS: Metabolic syndrome.}

\section{Acknowledgements}

Not applicable.

\section{Authors' contributions}

Idea/concept: Constructing the hypothesis or idea of research and/or article:IK, $A A, A D, C K, M E$. DESIGN:Planning methodology to reach the conclusions:IK, $A A, A D, C K, M E$. Control/supervision: Organizing, supervising the course of progress and taking the responsibility of the research/study:IK, AA, AD. Data collection and/or processing: Taking responsibility in patient follow-up, collection of relevant biological materials, data management and reporting, execution of the experiments:IK, AA, AD. Analysis and/or interpretation:Taking responsibility in logical interpretation and conclusion of the results:IK, AA, AD. Literature review: Taking responsibility in necessary literature review for the study:IK, AA, AD. Writing the article: Taking responsibility in the writing of the whole or important parts of the study:IK, AA, AD. Critical review: Reviewing the article before submission scientifically besides spelling and grammar:IK, AA, AD. References and fundings: Providing personnel, environment, financial support tools that are vital for the study:IK, AA, AD, CK, OD, CA. Materials: Biological materials, taking responsibility of the referred patients:IK, AA, AD, CK, OD, CA. All authors read and approved the final manuscript.

\section{Funding}

The funding agency has no role in the design of the study and in the collection, analysis and interpretation of data and writing of the manuscript.

\section{Availability of data and materials}

The datasets used and/or analysed during the current study are available from the corresponding author on reasonable request.

\section{Declarations}

Ethics approval and consent to participate Not applicable.

\section{Consent for publication}

Not applicable.

\section{Competing interests}

The authors declare that they have no competing interests.

\section{Author details}

${ }^{1}$ Division of Pediatric Hematology and Oncology, Department of Pediatrics, Faculty of Medicine, Ondokuz Mayıs University, Samsun, Turkey. ${ }^{2}$ Department of Pediatrics, Faculty of Medicine, Ondokuz Mayıs University, Samsun, Turkey. ${ }^{3}$ Division of Pediatric Endocrinology, Department of Pediatrics, Faculty of Medicine, Istinye University, Istanbul, Turkey. ${ }^{4}$ Division of Pediatric Hematology and Oncology, Department of Pediatrics, Faculty of Medicine, Medipol University Hospital, İstanbul, Turkey.

Received: 8 October 2021 Accepted: 7 January 2022

Published online: 24 January 2022 


\section{References}

1. Hancock SL, Hoppe RT, editors. Long-term complications of treatment and causes of mortality after Hodgkin's disease. Seminars in radiation oncology; 1996: Elsevier.

2. Siegel R, Ward E, Brawley O, Jemal A. Cancer statistics, 2011: the impact of eliminating socioeconomic and racial disparities on premature cancer deaths. CA Cancer J Clin. 2011:61(4):212-36.

3. Pui C-H, Pei D, Sandlund JT, Campana D, Ribeiro RC, Razzouk Bl, et al. Risk of adverse events after completion of therapy for childhood acute lymphoblastic leukemia. J Clin Oncol. 2005;23(31):7936-41.

4. Mertens AC, Yasui Y, Neglia JP, Potter JD, Nesbit ME Jr, Ruccione K, et al. Late mortality experience in five-year survivors of childhood and adolescent cancer: the Childhood Cancer Survivor Study. J Clin Oncol. 2001:19(13):3163-72

5. Pui C-H, Cheng C, Leung W, Rai SN, Rivera GK, Sandlund JT, et al. Extended follow-up of long-term survivors of childhood acute lymphoblastic leukemia. N Engl J Med. 2003;349(7):640-9.

6. Mody R, Li S, Dover DC, Sallan S, Leisenring W, Oeffinger KC, et al. Twenty-five-year follow-up among survivors of childhood acute lymphoblastic leukemia: a report from the Childhood Cancer Survivor Study. Blood, J Am Soc Hematol. 2008;111(12):5515-23.

7. Rogers PC, Meacham LR, Oeffinger KC, Henry DW, Lange BJ. Obesity in pediatric oncology. Pediatr Blood Cancer. 2005;45(7):881-91.

8. Taskinen M, Saarinen-Pihkala UM, Hovi L, Lipsanen-Nyman M. Impaired glucose tolerance and dyslipidaemia as late effects after bone-marrow transplantation in childhood. The Lancet. 2000;356(9234):993-7.

9. Grundy SM, Cleeman JI, Daniels SR, Donato KA, Eckel RH, Franklin BA, et al. Diagnosis and management of the metabolic syndrome: an American Heart Association/National Heart, Lung, and Blood Institute Scientific Statement. Circulation. 2005;112(17):2735-52.

10. Oeffinger KC, Buchanan GR, Eshelman DA, Denke MA, Andrews TC, Germak JA, et al. Cardiovascular risk factors in young adult survivors of childhood acute lymphoblastic leukemia. J Pediatr Hematol Oncol. 2001;23(7):424-30.

11. Neyzi O, Bundak R, Gökçay G, Günöz H, Furman A, Darendeliler F, et al. Reference values for weight, height, head circumference, and body mass index in Turkish children. J Clin Res Pediatr Endocrinol. 2015:7(4):280.

12. Hatipoglu N, Ozturk A, Mazicioglu MM, Kurtoglu S, Seyhan S, Lokoglu F. Waist circumference percentiles for 7-to 17-year-old Turkish children and adolescents. Eur J Pediatr. 2008;167(4):383-9.

13. Zimmet P, Alberti KGM, Kaufman F, Tajima N, Silink M, Arslanian S, et al. The metabolic syndrome in children and adolescents-an IDF consensus report. Pediatr Diabetes. 2007;8(5):299-306.

14. Tümer N, Yalcinkaya F, Ince E, Ekim M, Köse K, Cakar N, et al. Blood pressure nomograms for children and adolescents in Turkey. Pediatr Nephrol. 1999;13(5):438-43.

15. Withycombe JS, Smith LM, Meza JL, Merkle C, Faulkner MS, Ritter L, et al. Weight change during childhood acute lymphoblastic leukemia induction therapy predicts obesity: a report from the Children's Oncology Group. Pediatr Blood Cancer. 2015;62(3):434-9.

16. Scuri S, Petrelli F, Tesauro M, Carrozzo F, Kracmarova L, Grappasonni I. Energy drink consumption: a survey in high school students and associated psychological effects. J Prev Med Hyg. 2018;59(1):E75.

17. Molarius A, Seidell JC, Sans S, Tuomilehto J, Kuulasmaa K, Project WM. Varying sensitivity of waist action levels to identify subjects with overweight or obesity in 19 populations of the WHO MONICA Project. J Clin Epidemiol. 1999;52(12):1213-24.

18. Özcebe H, Tülay B, Keskinkılıç BYN, Çelikcan E. Çocukluk çağı obezite araştırması (COSI-TR) Ön Rapor. Ankara: Sistem Ofset. 2013:26-32.

19. T.C. Sağlık Bakanlığı Temel Sağlık Hizmetleri Genel Müdürlüğü. Türkiye'de Okul Çağı Çocuklarında (6-10 Yaş Grubu) Büyümenin İzlenmesi (Toçbi) Projesi Araştırma Raporu: Sağlık Bakanlığı Yayın No: 834; 2011.

20. Sancak R, Dündar C, Totan M, Çakır M, Sünter T, Küçüködük Ş. Ortaokul ve lise öğrencilerinde obezite prevalansı ve predispozan faktörler. J Exp Clin Med. 2010;16(1).

21. Ye JH, Shu XC, Chen P, Mai WH, Lang JM. Relationship of glucose metabolic rate and plasma levels of adiponectin and leptin in patients with metabolic syndrome. Zhonghua Yi Xue Za Zhi. 2011;91(16):1088-91.
22. Koyama S, Ichikawa G, Kojima M, Shimura N, Sairenchi T, Arisaka O. Adiposity rebound and the development of metabolic syndrome. Pediatrics. 2014;133(1):e114-9.

23. Gildner TE. Links between metabolic syndrome and the microbiome. Evol Med Public Health. 2020;2020(1):45-6.

24. Karaman S, Ercan O, Yıldız I, Bolayırlı M, Celkan T, Apak H, et al. Late effects of childhood ALL treatment on body mass index and serum leptin levels. J Pediatr Endocrinol Metab. 2010;23(7):669-74.

25. van Brussel M, Takken T, Lucia A, van der Net J, Helders PJ. Is physical fitness decreased in survivors of childhood leukemia? A systematic review. Leukemia. 2005;19(1):13-7.

26. Oeffinger KC, Sklar CA. Abdominal radiation and diabetes: one more piece in the puzzle. Lancet Oncol. 2012;13(10):961-2.

27. Gregoriou K, Craigie I, Gibson B, Mason A, Shaikh MG. Risk factors and management of corticosteroid-induced hyperglycaemia in paediatric acute lymphoblastic leukaemia. Pediatr Blood Cancer. 2020;67(2):e28085.

28. Chow EJ, Pihoker C, Hunt K, Wilkinson K, Friedman DL. Obesity and hypertension among children after treatment for acute lymphoblastic leukemia. Cancer. 2007;110(10):2313-20.

29. Widmer RJ, Lerman A. Endothelial dysfunction and cardiovascular disease. Global Cardiol Sci Pract. 2014;2014(3):43.

30. Cohen JB, Geara AS, Hogan JJ, Townsend RR. Hypertension in cancer patients and survivors: epidemiology, diagnosis, and management. Cardio Oncol. 2019;1(2):238-51.

31. Haddy TB, Mosher RB, Nunez SB, Reaman GH. Growth hormone deficiency after chemotherapy for acute lymphoblastic leukemia in children who have not received cranial radiation. Pediatr Blood Cancer. 2006;46(2):258-61.

32. Oudin C, Simeoni M-C, Sirvent N, Contet A, Begu-Le Coroller A, Bordigoni $\mathrm{P}$, et al. Prevalence and risk factors of the metabolic syndrome in adult survivors of childhood leukemia. Blood, J Am Soc Hematol. 2011;117(17):4442-8.

33. Neville KA, Cohn RJ, Steinbeck KS, Johnston K, Walker JL. Hyperinsulinemia, impaired glucose tolerance, and diabetes mellitus in survivors of childhood cancer: prevalence and risk factors. J Clin Endocrinol Metab. 2006:91(11):4401-7.

34. Trimis G, Moschovi M, Papassotiriou I, Chrousos G, Tzortzatou-Stathopoulou F. Early indicators of dysmetabolic syndrome in young survivors of acute lymphoblastic leukemia in childhood as a target for preventing disease. J Pediatr Hematol Oncol. 2007:29(5):309-14.

35. Nottage KA, Ness KK, Li C, Srivastava D, Robison LL, Hudson MM. Metabolic syndrome and cardiovascular risk among long-term survivors of acute lymphoblastic leukaemia-From the St. Jude Lifetime Cohort. Br J Haematol. 2014;165(3):364-74.

36. Kourti M, Tragiannidis A, Makedou A, Papageorgiou T, Rousso I, Athanassiadou F. Metabolic syndrome in children and adolescents with acute lymphoblastic leukemia after the completion of chemotherapy. J Pediatr Hematol Oncol. 2005;27(9):499-501.

37. Karakurt H, Sarper N, Kılıç SÇ, Gelen SA, Zengin E. Screening survivors of childhood acute lymphoblastic leukemia for obesity, metabolic syndrome, and insulin resistance. Pediatr Hematol Oncol. 2012;29(6):551-61.

38. Garmey EG, Liu Q, Sklar CA, Meacham LR, Mertens AC, Stovall MA, et al. Longitudinal changes in obesity and body mass index among adult survivors of childhood acute lymphoblastic leukemia: a report from the Childhood Cancer Survivor Study. J Clin Oncol. 2008;26(28):4639.

39. Oeffinger KC, Mertens AC, Sklar CA, Yasui Y, Fears T, Stovall M, et al. Obesity in adult survivors of childhood acute lymphoblastic leukemia: a report from the Childhood Cancer Survivor Study. J Clin Oncol. 2003;21(7):1359-65.

40. Janiszewski PM, Oeffinger KC, Church TS, Dunn AL, Eshelman DA, Victor $R G$, et al. Abdominal obesity, liver fat, and muscle composition in survivors of childhood acute lymphoblastic leukemia. J Clin Endocrinol Metab. 2007;92(10):3816-21.

41. Jarfelt M, Lannering B, Bosaeus I, Johannsson G, Bjarnason R. Body composition in young adult survivors of childhood acute lymphoblastic leukaemia. Eur J Endocrinol. 2005:153(1):81-9.

42. Arguelles B, Barrios V, Buno M, Madero L, Argente J. Anthropometric parameters and their relationship to serum growth hormone-binding protein and leptin levels in children with acute lymphoblastic leukemia: a prospective study. Eur J Endocrinol. 2000;143(2):243-50. 
43. Renehan AG, Roberts DL, Dive C. Obesity and cancer: pathophysiological and biological mechanisms. Arch Physiol Biochem. 2008;114(1):71-83.

44. Razzouk BI, Rose SR, Hongeng S, Wallace D, Smeltzer MP, Zacher M, et al. Obesity in survivors of childhood acute lymphoblastic leukemia and lymphoma. J Clin Oncol. 2007;25(10):1183-9.

45. Karakaya P, Yılmaz S, Tüfekçi O, Kır M, Böber E, Irken G, et al. Endocrinological and cardiological late effects among survivors of childhood acute lymphoblastic leukemia. Turk J Haematol. 2013;30(3):290-9.

46. Asner S, Ammann R, Ozsahin H, Beck-Popovic M, Von der Weid N. Obesity in long-term survivors of childhood acute lymphoblastic leukemia. Pediatr Blood Cancer. 2008;51(1):118-22.

47. Zhang FF, Rodday AM, Kelly MJ, Must A, MacPherson C, Roberts SB, et al. Predictors of being overweight or obese in survivors of pediatric acute lymphoblastic leukemia (ALL). Pediatr Blood Cancer. 2014;61(7):1263-9.

48. Köksal G, Özel HG. Okul Öncesi Dönemde Obezite. TC Sağlık Bakanlığı Temel Sağlık Hizmetleri Genel Müdürlüğü Beslenme ve Fiziksel Aktiviteler Daire Başkanlığı Yayınları, Ankara. 2008.

49. Rokitka DA, Curtin C, Heffler JE, Zevon MA, Attwood K, Mahoney MC. Patterns of loss to follow-up care among childhood cancer survivors. J Adolesc Young Adult Oncol. 2017;6(1):67-73.

\section{Publisher's Note}

Springer Nature remains neutral with regard to jurisdictional claims in published maps and institutional affiliations.

- fast, convenient online submission

- thorough peer review by experienced researchers in your field

- rapid publication on acceptance

- support for research data, including large and complex data types

- gold Open Access which fosters wider collaboration and increased citations

- maximum visibility for your research: over $100 \mathrm{M}$ website views per year

At BMC, research is always in progress.

Learn more biomedcentral.com/submissions 